\title{
Saccharomyces cerevisiae Ghosts Using the Sponge-Like Re-Reduced Protocol
}

\author{
Amro Abd Al Fattah Amara* \\ Head of the Protein Research Department, Genetic Engineering and Biotechnology Research Institute, City for Scientific \\ Research and Technological Applications, Egypt
}

\begin{abstract}
Received: 15 August, 2015; Accepted: 02 September, 2015; Published: 30 September, 2015
*Corresponding author: Amro Abd Al Fattah Amara, Head of the Protein Research Department, Genetic Engineering and Biotechnology Research Institute, City for Scientific Research and Technological Applications, New Borg Al Arab, Alexandria, Egypt; Tel: +203-4593422; Fax: 203-4593497; E-mail: amroamara@web.de
\end{abstract}

\begin{abstract}
Sponge-Like protocol for Ghosts preparation showing an increasing interest while it exceed the range of the $E$ lysis gene protocol for Bacterial Ghosts preparation which is restricted only to gram-negative bacteria. The protocol can be used for nearly all bacterial strains. In this study, it succeeded for the first time to produce ghosts from Eukaryotic cell. In this study, S. cerevisiae yeast was turned to Ghost cells using Sponge-Like protocol for Ghosts preparation. However, centrifugation step was eliminated to avoid self-adhering or shrinking of the yeast empty cells. Instead, decantation was used. One unique properties of the yeast is that, it is able to decant. The protocol for ghost cells preparation was also reduced to use only the Minimum Inhibitory Concentration (MIC) of each of $\mathrm{NaOH}, \mathrm{SDS}, \mathrm{NaHCO}_{3}$ and $\mathrm{H}_{2} \mathrm{O}_{2} \cdot \mathrm{NaHCO}_{3}$ was used instead of $\mathrm{CaCO}_{3}$ due to the variation in the cell wall between the prokaryotic (Bacteria) and the eukaryotic (yeast) cells. Light and Scanning electron microscope were used to evaluate the quality of the S. cerevisiae Ghosts (S.c.Gs). Spectrophotometer was used to evaluate the amount of the realized DNA and Protein. The study show successful yeast ghost preparation with correct 3D structure.
\end{abstract}

Keywords: Saccharomyces cerevisiae Ghosts; Critical Chemical Concentration; Scanning Electron Microscope

\section{Introduction}

Microbial Ghosts are the microbes after their evacuation from their cytoplasmic content without damaging their 3D structures. Yeast is an old microbe used in traditional biotechnology [1]. Yeast has showing increasing interest in various biotechnological applications due to its different properties, which were extended by the genetic engineering and molecular biology tools [27]. Yeast is an eukaryotic microorganism which has some unique properties different from bacterial cells [2,8-10]. Being eukaryotic, yeasts enable the correct expression for different types of recombinant proteins $[2,11,12]$. For more information about the different human proteins produced and expressed in the yeasts refer to Service (2003) and the references within [13]. Regarding to its big size the yeast cell could be used as drug delivery system [14-19]. Yeast Ghosts preparation was reported using some conformational isomers of pancreatic [20]. This study for the first time shows a new protocol for preparing S. cerevisiae Ghosts.

\section{Material and Methods}

\section{Yeast Strain, Media and Growth Conditions}

S. cerevisiae strain bought from local market in Egypt as dry granules (Germapan company-Casablanca-Morocco) was used in this study. The strain was purified using striking methods on Rose Bengal Chloramphenicol agar.

For regular cultivation, the following designed medium has been used: broth medium (one Liter); $5 \mathrm{gm}$ peptone; $3 \mathrm{gm} \mathrm{NaCl}$ and $5 \mathrm{gm}$ glucose. For solid medium, 12gm/L agar was added. The cultivation temperature was $26^{\circ} \mathrm{C}$.

\section{Determination of the Minimum Inhibition Concentration (MIC)}

Determination of the Minimum Inhibitory Concentration (MIC) for each of $\mathrm{NaOH}, \mathrm{SDS}, \mathrm{NaHCO}_{3}$ and $\mathrm{H}_{2} \mathrm{O}_{2}$ was conducted using standard experiment for determining the MIC as described by Amara et al. [21].

$\mathrm{NaOH}, \mathrm{SDS}, \mathrm{NaHCO}_{3}$ were prepared as $10 \%$ sterile stock solutions. SDS, $\mathrm{NaHCO}_{3}$ were sterilized using the autoclave. $\mathrm{NaOH}$ did not autoclaved while it is sterile by itself at $10 \%$ concentration. $\mathrm{H}_{2} \mathrm{O}_{2}$ was purchased from local pharmacy as $30 \%$ sterile solution. $0.5 \mathrm{ml}$ of each (of the above-described compounds) was used to conduct the serial dilution experiment. For each compound $0.5 \mathrm{ml}$ was added to the first tube in which, the tube contains $4.5 \mathrm{ml}$ of the above described broth cultivation medium. $0.5 \mathrm{ml}$ was then transferred from the first test tube to the second one and so on until seven tubes for each compound. The tubes were then mixed gently. For the last tube, $0.5 \mathrm{ml}$ was discharged. Each tube was then inoculated with $100 \mu \mathrm{l}$ of the freshly prepared $\left(10^{8} \mathrm{CFU} / \mathrm{ml}\right)$ $S$. c. culture. The tubes then mixed gently and left for $48 \mathrm{~h}$. The $S$. c. growth was observed by increasing the amount of sediment cells in the test tube bottom. 


\section{S.c.Gs Preparation Using Re-Reduced SL Protocol}

One gram of the dried yeast cells was added to $10 \mathrm{ml}$ of the MIC of the $\mathrm{NaHCO}_{3}$ and subjected to gentle shaking for one hr. Then the yeast cells left static to enable the cells to sediment. Sample from the supernatant was taken to determine the amount of the realized DNA and Protein. The supernatant then discharged and the cells washed by distilled water, left for decantation and the supernatant discharged. The same steps were repeated for each of $\mathrm{NaOH}, \mathrm{SDS}$, and $\mathrm{H}_{2} \mathrm{O}_{2}$. Finally, the cells washed by $60 \%$ ethanol and left suspended in ethanol at $4^{\circ} \mathrm{C}$.

\section{S.c.Gs Evaluation Using Light Microscope}

Yeast smear for the treated cells was prepared using standard criteria followed by crystal violet stain. The cells were examined by the aid of the light microscope. The quality of the cells was determined based on the yeast 3D structure as either being correct or deformed.

\section{Determination of the DNA Concentration}

The concentration of the DNA was determined by measuring the absorption at $260 \mathrm{~nm}$. Quartz cuvette was used. An extinction $260=1$ corresponds to $50 \mu \mathrm{g}$ dsDNA $\mathrm{mL}^{-1}$ [22].

\section{Determination of the Protein Concentration}

Protein analysis of each experiment (the different supernatants) was determined using the spectrophotometer at $280 \mathrm{~nm}$. Quartz cuvette was used. The different protein concentrations were derived from Bovine Serum Albumin standard curve.

\section{Sample Preparation for Electron Microscope Examination}

For further study to the yeast, Ghosts quality electron microscope was used to scan the bacterial cells. Dry yeast smear was prepared and the smear surface then coated with approximately $15 \mathrm{~nm}$ gold (SPI-Module Sputter Coater).

\section{Scanning of the yeast Surface}

The golden-coated sample was then scanned by analytical scanning electron microscope (Jeal JSM-6360LA) with secondary element at $10 \mathrm{kv}$ accelerating voltages at room temperature. The digital images then were adjusted and saved.

\section{Result and Discussion}

This study describes for first time the production of $S$. cerevisiae Ghosts. The main aim of this study is to prepare $S$. cerevisiae Ghosts. Recently, Amara et al. [21], have reported a new protocol for Ghosts preparations. The protocol is mainly based on using critical chemical concentration for some chemical compounds are able to introduce genteel pores in the E. coli cells. The original protocol including the use of Plackett Burman experimental design to map the best conditions for obtaining successful Ghosts cells. The protocol was validated in several published papers. The protocol show successful Ghosts preparation from E. coli BL21 and JM109, show sensitivity and prove different MIC between those both similar strains.
MIC concentration is a critical point where the used chemical compound kills the cells with the minimum expected damage. The protocol was reduced to be simpler and more practical where the best two experiments obtained from the PlackettBurman experiment were used only and the MIC and MGC were used to specify the critical point for killing cells without causing any damage. The produced Ghosts from Salmonella typhimurium ATCC 14028 show the sensitivity of such protocol and correct surface antigens maintained during the preparation steps. Such protocol has extended the Bacterial Ghosts preparation, which was prepared using the bacteriophage $E$ lysis gene. It extends its range from only gram-negative bacteria, which restricted due to the function activity of the $E$ lysis gene to nearly all bacterial types. Additionally, Newcastle virus was prepared as Ghosts [23].

Moreover, this study adds the first Eukaryotic cell prepared using such protocol. The Ghosts preparation protocol was rereduced in this study and only MIC concentration of the used chemical compounds were used. $\mathrm{NaHCO}_{3}$ was used instead of $\mathrm{CaCO}_{3}$ while it proves to be more powerful against Eukaryotic cells as proved by Amara and Steinbüchels 2014 [21]. Yeast cells are bigger than the bacterial cells and they have unique properties that they are able to sediment. For that, centrifugation was not used in this study and only decantation was used. This was planed also, because centrifugation cause Yeasts Ghosts to shrink and their empty inside space when subjected to the centrifugation force which cause the cells to deform or to come together as an empty balloon. As described in the original protocol the Yeast Ghosts DNA and protein losing were determined using the spectrophotometer at 260 and $280 \mathrm{~nm}$ respectively (data not shown). The amount of the realized protein and DNA show correct evacuation of the yeast cells from their cytoplasmic content as described in the original protocol by Amara et al. [21]. The cells with different qualities were monitored using light microscope and electron microscope as in figures 1-3. Both of the light and the electron microscope show correct 3D structure for the prepared yeast Ghosts as in the Figures 1-3.

The study show correct preparation for yeast ghosts could be used in various applications.

\section{Conclusion}

This study show for the first time Yeast Ghosts prepared

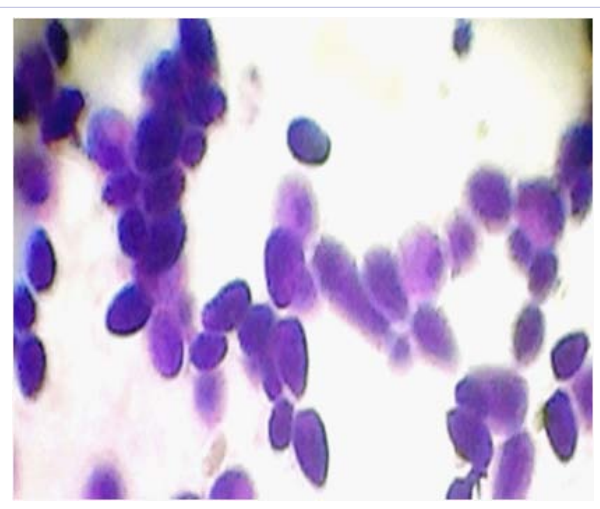

Figure 1: Viable S. cerevisiae cells (before treatment) stained by crystal violet using light microscope. 


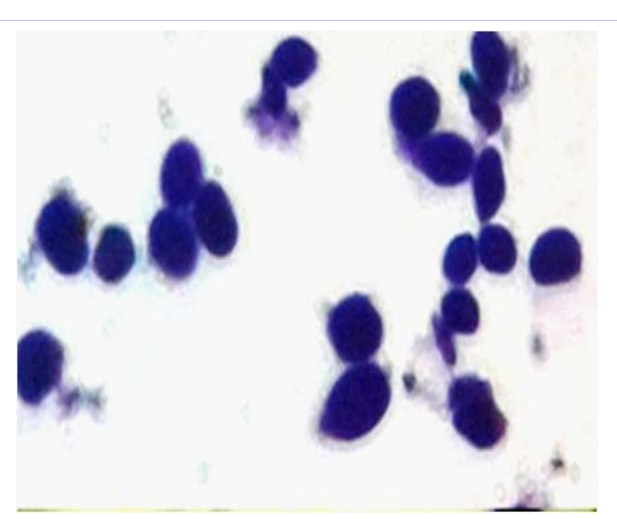

Figure 2: Ghost $S$. cerevisiae cells (after treatment) stained by crystal violet using light microscope .

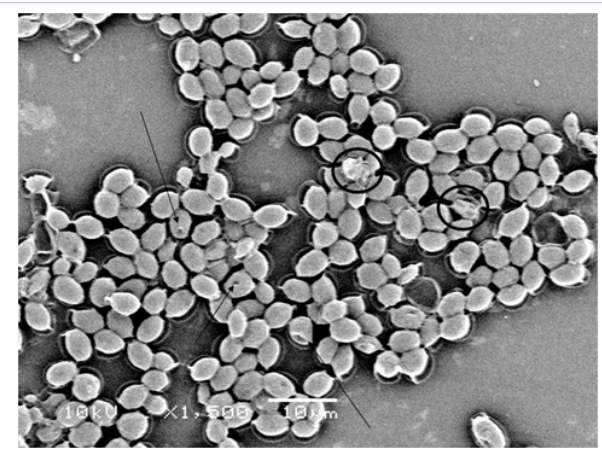

Figure 3: S. cerevisiae ghost cells, Image taken by scanning electron microscope (1500X). Arrows show pores in the Ghost cells.

using the critical chemical concentration of the $\mathrm{NaOH}, \mathrm{SDS}$, $\mathrm{NaHCO}_{3}$ and $\mathrm{H}_{2} \mathrm{O}_{2}$. These compounds and by following the concept of the Sponge-Like protocol for preparing Bacterial Ghosts succeeded to prepare yeast Ghosts. Simply, MIC for each has been determined and has been used in steps to induce gentle pore(s) in the yeast cells as well as to evacuate their cytoplasmic contents. The light microscope as well as the electron microscope show correct 3D structure and correct pores in the yeast cells. The spectrophotometer proves correct release for both of the protein and the DNA, which are indications about the evacuation of the yeast cells from their cytoplasmic contents. Such a succeed in the yeast cells preparation open a new area for both drug delivery and vaccination using yeast cells either as carriers for surface foreign proteins or a package can be loaded with proteins as well as for a bigger candidates for loading different drugs and can be used successfully in drug delivery technology.

\section{References}

1. Maraz A. Impact of yeast genetics and molecular biology on traditional and new biotechnology. Acta Microbiol Immunol Hung. 1999; 46(2-3): 289-95.

2. Cereghino GP, Cregg JM. Applications of yeast in biotechnology: protein production and genetic analysis. Curr Opin Biotechnol. 1999; 10(5): 422-7.

3. Graf A, Dragosits M, Gasser B, Mattanovich D. Yeast systems biotechnology for the production of heterologous proteins. FEMS Yeast
Res. 2009; 9(3): 335-48. doi: 10.1111/j.1567-1364.2009.00507.x.

4. Jacob Z. Yeast lipid biotechnology. Adv Appl Microbiol. 1993; 39: 185212.

5. Maraz A. From yeast genetics to biotechnology. Acta Microbiol Immunol Hung. 2002; 49(4): 483-91.

6. Méndez B, Valenzuela P. Recombinant yeast as a production system in biotechnology. Bioprocess Technol. 1991; 13: 16-53.

7. Passoth V, Fredlund E, Druvefors UA, Schnürer J. Biotechnology, physiology and genetics of the yeast Pichia anomala. FEMS Yeast Res. 2006; 6(1): 3-13.

8. Hamasaki M, Noda T, Baba M, Ohsumi Y. Starvation triggers the delivery of the endoplasmic reticulum to the vacuole via autophagy in yeast. Traffic. 2005; 6(1): 56-65.

9. Harashima S, Kaneko Y. Application of the PHO5-gene-fusion technology to molecular genetics and biotechnology in yeast. J Biosci Bioeng. 2001; 91(4): 325-38.

10. Kajiwara K, Watanabe R, Pichler $H$, Ihara K, Murakami S, Riezman $\mathrm{H}$, et al. Yeast ARV1 is required for efficient delivery of an early GPI intermediate to the first mannosyltransferase during GPI assembly and controls lipid flow from the endoplasmic reticulum. Mol Biol Cell. 2008; 19(5): 2069-82. doi: 10.1091/mbc.E07-08-0740.

11. Reyes-Becerril M, Salinas I, Cuesta A, Meseguer J, Tovar-Ramirez D, Ascencio-Valle F, et al. Oral delivery of live yeast Debaryomyces hansenii modulates the main innate immune parameters and the expression of immune-relevant genes in the gilthead seabream (Sparus aurata L.). Fish Shellfish Immunol. 2008; 25(6): 731-9. doi: 10.1016/j.fsi.2008.02.010.

12.Zhang M, Li S, Nyati MK, DeRemer S, Parsels J, Rehemtulla A, Regional delivery and selective expression of a high-activity yeast cytosine deaminase in an intrahepatic colon cancer model. Cancer Res. 2003; 63(3): 658-63.

13. Service RF. Biotechnology. Yeast engineered to produce sugared human proteins. Science. 2003; 301(5637): 1171.

14. Bianchi A, Negrini S, Shore D. Delivery of yeast telomerase to a DNA break depends on the recruitment functions of Cdc13 and Est1. Mol Cell. 2004; 16(1): 139-46.

15. Cowles CR, Snyder WB, Burd CG, Emr SD. Novel Golgi to vacuole delivery pathway in yeast: identification of a sorting determinant and required transport component. EMBO J. 1997; 16(10): 2769-82.

16. Henkel MK, Pott G, Henkel AW, Juliano L, Kam CM, Powers JC,Endocytic delivery of intramolecularly quenched substrates and inhibitors to the intracellular yeast Kex2 protease1. Biochem J. 1999; 341 ( Pt 2): 44552.

17. Kingsman AJ, Burns NR, Layton GT, Adams SE. Yeast retrotransposon particles as antigen delivery systems. Ann N Y Acad Sci. 1995; 754: 202-13.

18. Pedersen GT. Yeast flora in mother and child. A mycological-clinical study of women followed up during pregnancy, the puerperium and 5-12 months after delivery, and of their children on the 7th day of life and at the age of 5-12 months. Dan Med Bull. 1969; 16(7): 207-20.

19. Stepp JD, Huang K, Lemmon SK. The yeast adaptor protein complex, AP-3, is essential for the efficient delivery of alkaline phosphatase by the alternate pathway to the vacuole. J Cell Biol. 1997; 139(7): 176174 .

20. Alper RE, Dainko JL, Schlenk F. Properties of yeast cell ghosts obtained 
by ribonuclease action. J Bacteriol. 1967; 93(2): 759-65.

21. Amara AA, Salem-Bekhit MM, Alanazi FK. Sponge-like: a new protocol for preparing bacterial ghosts. ScientificWorldJournal. 2013; 2013:545741. doi: $10.1155 / 2013 / 545741$.

22. Sambrook J, Fritsch EF and Mainiatis . Molecular Cloning a Laboratory
Manual. $2^{\text {nd }}$ edition. NY, USA: Cold Spring Harbor Laboratory; 1989.

23. Abd El-Baky N, Amara AA. Newcastle disease virus (LaSota strain) as a model for virus Ghosts preparation using $\mathrm{H}_{2} \mathrm{O}_{2}$ biocritical concentration. International Science and Investigation Journal. 2014; $3(5)$. 